\title{
Zymosan promotes proliferation, Candida albicans adhesion and IL-1 $\beta$ production of oral squamous cell carcinoma in vitro
}

\author{
Xu Chen ${ }^{1 \dagger}$, Qingqiong Luo ${ }^{1 \dagger}$, Jieying Ding ${ }^{1}$, Meng Yang ${ }^{1}$, Ruiyang Zhang ${ }^{1}$ and Fuxiang Chen ${ }^{1,2^{*}}$
}

\begin{abstract}
Oral squamous cell carcinoma (OSCC) is the most common type of head and neck squamous cell carcinoma (HNSCC), and the effect of zymosan (ZYM), a component of the yeast cell wall, on oral cancer remains unclear. The CCK-8 proliferation assay was performed to evaluate the effect of ZYM on the proliferation of the OSCC cell lines WSU-HN4, WSU-HN6 and CAL27, and the potential mechanism was explored by quantitative real-time PCR, immunofluorescence assay and western blot. A cell adhesion assay was conducted to determine the adhesion of Candida albicans to OSCC cells, and the expression of related genes, including TLR2, MyD88, NLRP3, ASC, Caspase- 1 and IL-1 $\beta$, and proteins, including TLR2, MyD88, NF-KB p65, p-NF-KB p65 and E-cadherin was determined. Additionally, the pro-inflammatory cytokines including IL-6, IL-8, TNF- $a$ and IL-1 $\beta$ produced by OSCC cells were detected using a chemiluminescence immunoassay (CLIA). In the current study, the CCK-8 assay showed that ZYM promoted the proliferation of WSU-HN4, WSU-HN6 and CAL27 cells via the TLR2/MyD88 pathway. The cell adhesion assay showed that the number of C. albicans cells per field significantly increased in ZYM-treated OSCC cells compared to controls. When treated with ZYM, OSCC cells secreted significantly more pro-inflammatory cytokine IL-1 $\beta$, which could enhance inflammation in oral cancer microenvironment. In conclusion, ZYM from the fungal cell wall promotes the proliferation, $C$. albicans adhesion and IL-1 $\beta$ production in OSCC, as demonstrated by in vitro experiments.
\end{abstract}

Keywords: Zymosan, Candida albicans, Proliferation, Oral cancer, Oral squamous cell carcinoma

\section{Introduction}

Oral squamous cell carcinoma (OSCC) is the most common type of head and neck squamous cell carcinoma (HNSCC), which is the sixth leading cancer type worldwide [1]. The most common treatment for oral cancers involves radical surgery and chemotherapy, including 5fluorouracil and cisplatin. However, the 5-year survival rate among patients with OSCC is low because of the poor prognosis, such as the occurrence of lymph node

\footnotetext{
*Correspondence: chenfx@sjtu.edu.cn

${ }^{+} \mathrm{Xu}$ Chen and Qingqiong Luo contributed equally to this work.

'Department of Clinical Immunology, Shanghai Ninth People's Hospital, Shanghai Jiao Tong University School of Medicine (SJTUSM), Shanghai 200011, China

${ }^{2}$ Faculty of Medical Laboratory Science, Shanghai Jiao Tong University School of Medicine (SJTUSM), Shanghai 200025, China
}

metastasis and local recurrence [2]. Recently, imbalanced microbiota or specific microbes have been found to play an indispensable role in tumour initiation, progression and even chemoresistance [3-6]. For example, Helicobacter pylori plays a role in inducing or promoting gastric cancer [7], and different microorganisms, such as Fusobacterium sp., Porphyromonas gingivalis and Candida albicans, have been reported in oral cancers [8-10].

It has been observed that oral carriage of $C$. albicans is higher in patients with OSCC or leukoplakia than in those without oral pathology [11, 12], but the association between C. albicans and oral cancer remains ambiguous. Several reports have proposed different potential pathways by which $C$. albicans initiates or promotes carcinogenesis, such as inducing inflammation [13, 14]. Triggering of

(c) The Author(s). 2020 Open Access This article is licensed under a Creative Commons Attribution 4.0 International License, which permits use, sharing, adaptation, distribution and reproduction in any medium or format, as long as you give appropriate credit to the original author(s) and the source, provide a link to the Creative Commons licence, and indicate if changes were made. The images or other third party material in this article are included in the article's Creative Commons licence, unless indicated otherwise in a credit line to the material. If material is not included in the article's Creative Commons licence and your intended use is not permitted by statutory regulation or exceeds the permitted use, you will need to obtain permission directly from the copyright holder. To view a copy of this licence, visit http://creativecommons.org/licenses/by/4.0/ The Creative Commons Public Domain Dedication waiver (http://creativecommons.org/publicdomain/zero/1.0/) applies to the data made available in this article, unless otherwise stated in a credit line to the data. 
inflammation by inducing TNF- $\alpha$ and IL- 8 or production of carcinogenic by-products such as nitrosamine and $\mathrm{N}$ nitrosobenzylmethylamine (NBMA) by $C$. albicans could be a risk factor for cancer [15]. Therefore, it is important to investigate the interaction between microorganisms and host cells. The adhesion of microorganisms to host cells has been reported to be the first step for bacteria or fungi to influence host cells [8]. However, the adhesion of C. albicans to OSCC cells remains unclear.

Toll-like receptors (TLRs) and other pattern recognition receptors (PRRs) play a significant role in the recognition of pathogens and triggering of innate immune responses, and a group of molecules can act as pathogen-associated molecular patterns (PAMPs), such as glucans, which are recognized by PRRs [16]. Moreover, the OSCC cells have been found to express different TLRs, including TLR3 and TLR4 [17]. Activation of TLRs usually induces recruitment of the adapter molecule myeloid differentiation primary response protein 88 (MyD88), and activation of $\mathrm{TLR} / \mathrm{MyD} 88$ typically leads to the activation of NF- $\mathrm{kB}$, which has been linked to the progression of tumours [18]. However, the role of TLR expressed on OSCC cells in the interaction with microbial components needs to be investigated. This study aimed to define the effect of zymosan (a component of the fungal cell wall, ZYM), which is a glucan with repeating glucose units connected by $\beta-1,3-$ glycosidic linkages, on oral cancer by investigating the proliferation and cytokine production of OSCC cells and C. albicans adhesion to cell lines.

\section{Materials and methods}

\section{Cell lines and reagents}

In this study, the human OSCC cell lines WSU-HN4, WSU-HN6 and CAL27 were cultured in Dulbecco's modified Eagle's medium (DMEM) supplemented with 10\% fetal bovine serum (Gibco, New York, NY, USA) and 1\% penicillin-streptomycin. All cells were incubated in a humidified atmosphere containing $5 \% \mathrm{CO}_{2}$ at $37^{\circ} \mathrm{C}$. Zymosan was purchased from Sangon Biotech (Shanghai, China). $C$. albicans ATCC 90028 was cultured on Sabouraud Dextrose Agar (SDA) at $37^{\circ} \mathrm{C}$ in an incubator containing $5 \% \mathrm{CO}_{2}$.

\section{CCK-8 cell viability assay}

The cell viability assay was performed with CCK-8 (Dojindo, Kumamoto, Japan). OSCC cells (5000 cells/ well) were seeded into 96-well plates and cultured for $12-24 \mathrm{~h}$ before treatment. The OSCC cells were treated with zymosan $(10 \mu \mathrm{g} / \mathrm{ml}$ and $100 \mu \mathrm{g} / \mathrm{ml})$ or with $100 \mu \mathrm{L}$ PBS as the control. After $12 \mathrm{~h}, 24 \mathrm{~h}$ or $48 \mathrm{~h}$ of treatment, $10 \mu \mathrm{L}$ of CCK- 8 reagent was added, and the optical density was read at $450 \mathrm{~nm}$ on a microplate reader (BioRad, Hercules, CA, USA) after incubation for $1.5 \mathrm{~h}$.

\section{Cell adhesion assay}

OSCC cell suspension was seeded onto a coverslip placed in a 24-well plate, which was disinfected by UV light, and the cells were incubated for $24 \mathrm{~h}$ to attach to coverslip, and then stimulated by zymosan or PBS for an additional $24 \mathrm{~h}$. The cells were washed with PBS before adding C. albicans suspension in PBS, and were further incubated at $37{ }^{\circ} \mathrm{C}$ with $5 \% \mathrm{CO}_{2}$ for $1 \mathrm{~h}$. After incubation, the DMEM with unattached yeast was aspirated, and each well was washed with PBS and then fixed with 95\% ethanol for $1 \mathrm{~h}$. After that, the coverslip was removed for Gram staining.

\section{Cytokine detection}

OSCC cells were seeded into a 12-well plate before treatment with PBS or zymosan, and then supernatants were collected to measure the concentrations of IL-1 $\beta$, IL-6, IL8 and TNF- $\alpha$. These cytokines were measured by chemiluminescence immunoassay (CLIA) using IMMULITE $^{\circ} 1000$ (SIEMENS, Germany) with commercial reagents according to the manufacturer's instructions.

\section{Quantitative real-time PCR}

Total RNA was extracted using TRIzol reagent (Invitrogen, San Diego, CA, USA), and real-time PCR amplification was carried out by a two-step reaction. First, cDNA was synthesized by GeneAmp ${ }^{\circ}$ PCR system 9700 (Applied Biosystems) with PrimeScript ${ }^{\mathrm{Tw}}$ RT Reagent kit (TaKaRa, Shiga, Japan), and then real-time PCR was performed in the 7500 system (Applied Biosystems) with SYBR Premix Ex Taq II (TaKaRa). The experiment was repeated in triplicate on independent occasions. The $G A P D H$ gene was used for the normalization of gene expression, and the relative expression of TLR2, MyD88, NLRP3, ASC, Caspase- 1 and $I L-1 \beta$ was determined using the $2^{-\Delta \Delta \mathrm{Ct}}$ method.

\section{Western blot}

OSCC cells treated with zymosan $(100 \mu \mathrm{g} / \mathrm{mL})$ were collected and lysed on ice in RIPA buffer with phosphatase inhibitor (Solarbio, Beijing, China) and phenylmethanesulfonylfluoride (PMSF). After centrifugation, the protein concentration in supernatants was determined by an Enhanced BCA Protein Assay Kit (Beyotime, Haimen, China), and the protein samples were then incubated at $100^{\circ} \mathrm{C}$ for $10 \mathrm{~min}$. Equal amounts of total protein were subjected to SDS-polyacrylamide gel electrophoresis (SDS-PAGE) and then electrophoretically transferred onto a polyvinylidene difluoride (PVDF) membrane (Bio-Rad, Hercules, CA, USA). The membrane was blocked in $5 \%$ nonfat milk powder in Tris-buffered saline/Tween 20 (TBST) for $1 \mathrm{~h}$ at room temperature and incubated with primary antibody overnight at $4{ }^{\circ} \mathrm{C}$ (TLR2, ab16894, Abcam; MyD88, ab133739, Abcam; E- 
cadherin, ab40772, Abcam; NF-кB p65, \#8242, Cell Signaling Technology; p-NF-кB, \#3033, Cell Signaling Technology and $\beta$-actin, A1978, SIGMA) and then incubated with HRP-conjugated secondary antibodies (antirabbit IgG from Sigma-Aldrich and anti-mouse IgG from Cell Signaling Technology) at a dilution of 1:5000 for $1 \mathrm{~h}$ at room temperature. Protein bands were visualized using High-sig ECL substrate and a Tanon 5200 CE machine (Tanon, Shanghai, China).

\section{Immunofluorescence assay}

The OSCC cells treated with PBS or zymosan and placed on glass slides were fixed with $4 \%$ paraformaldehyde for 20 min, permeabilized with $0.1 \%$ Triton X-100 for 3 min and blocked with $5 \%$ bovine serum albumin for $30 \mathrm{~min}$. The slides were incubated with anti-TLR2 antibody (1: 10, Abcam, MA, USA) at $4{ }^{\circ} \mathrm{C}$ overnight. Anti-mouse IgG antibody with Alexa Fluor 568 served as secondary antibody (Thermo Fisher Scientific, USA). After washing three times with TBST, the cells were stained with DAPI for $3 \mathrm{~min}$ to visualize the nuclei. Images were taken by an inverted microscope equipped with fluorescence optics (Olympus, Osaka, Japan).

\section{Statistical analysis}

The data were displayed as the mean \pm standard deviation, and processed by GraphPad Prism 5 (version 5.01, GraphPad Software, CA, USA). Statistical analysis was conducted by SAS 8.2 (SAS Institute Inc., Cary, NC, USA). Two-tailed $P$-value less than 0.05 was considered statistically significant and was indicated with * when $P<0.05$, ** when $P<0.01$, *** when $P<0.001$ and $*$ wow $P<0.0001$.

\section{Results}

\section{Zymosan from the fungal cell wall promotes the} proliferation of OSCC

To investigate the effect of ZYM on oral cancer cells, we cultured OSCC cell lines (WSU-HN4, WSU-HN6 and CAL27) with zymosan at the concentrations of $10 \mu \mathrm{g} / \mathrm{ml}$ and $100 \mu \mathrm{g} / \mathrm{ml}$ for $12 \mathrm{~h}, 24 \mathrm{~h}$ or $48 \mathrm{~h}$. There was no influence on the growth of OSCC cells when the zymosan concentration was $10 \mu \mathrm{g} / \mathrm{ml}$. However, zymosan promoted the proliferation of OSCC cells in vitro according to the results of the CCK- 8 assay when the concentration was $100 \mu \mathrm{g} / \mathrm{ml}$ (Fig. 1). The results indicated that a tumour-promoting effect could be induced by zymosan or other glucan-containing pathogens such as $C$. albicans, at a high concentration.

\section{The TLR2/MyD88 pathway is involved in the interaction between OSCC and zymosan}

To define the receptors of zymosan in OSCC cells, the mRNA expression of receptors including TLR2, TLR6, Dectin-1 and CR3 was detected by quantitative real-time PCR (RT-PCR). The results suggested that TLR2 is expressed on OSCC cells and that TLR2 is more highly expressed when the cells were treated with zymosan (Fig. 2a and b). Elevated expression of TLR2 on OSCC cells treated with zymosan was also found by immunofluorescence assay (Fig. 2c). By RT-PCR and western blot, the expression of the downstream adapter molecule MyD88 was also found to be elevated, indicating that the TLR2/MyD88 pathway is involved in the process of stimulation. The activation of NF- $\mathrm{kB}$, which is commonly induced by TLR2/MyD88, has been linked to the progression of tumours. As shown in Fig. 2b, phosphorylated-NFкB p65 protein levels were significantly increased in OSCC cells treated with zymosan compared with those without zymosan. These results indicated that zymosan could facilitate the proliferation of OSCC in vitro by activating NF- $\kappa B$ via the TLR2/MyD88 pathway.

\section{Increased adhesion of C. albicans onto OSCC treated with zymosan}

Clinical observations have indicated an association between $C$. albicans and oral cancers. In the cell adhesion test, the number of $C$. albicans cells per oil field was significantly increased in ZYM-treated OSCC cells compared to controls (Fig. 3a), suggesting increased adhesion of C. albicans onto ZYM-treated OSCC cells. After summarizing the total number of $C$. albicans cells from 20 oil fields, a significant increase in C. albicans cells was found on the surface of ZYM-treated OSCC cells

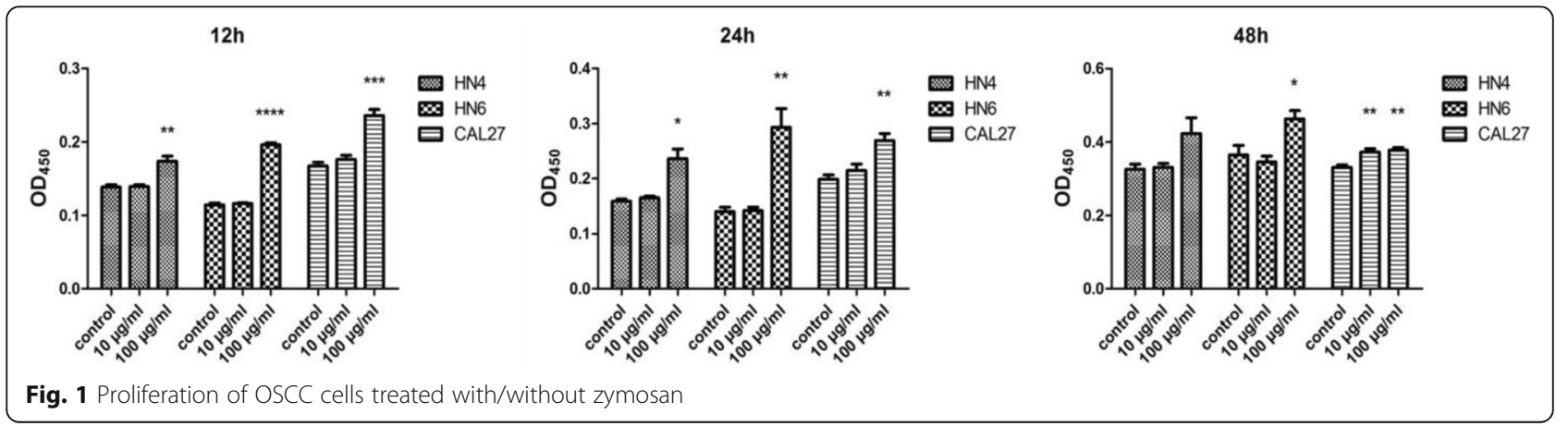



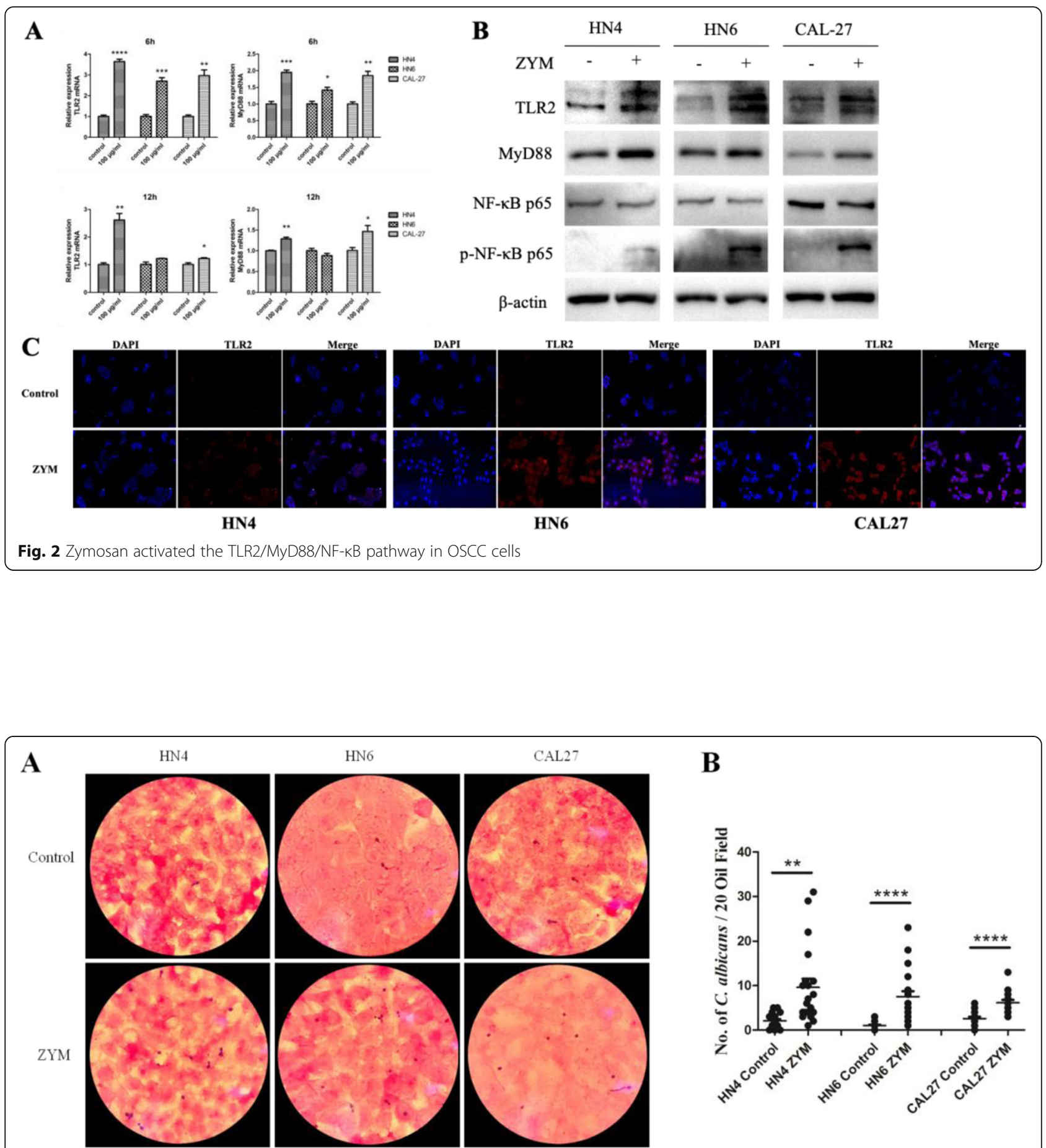

$\mathbf{B}$

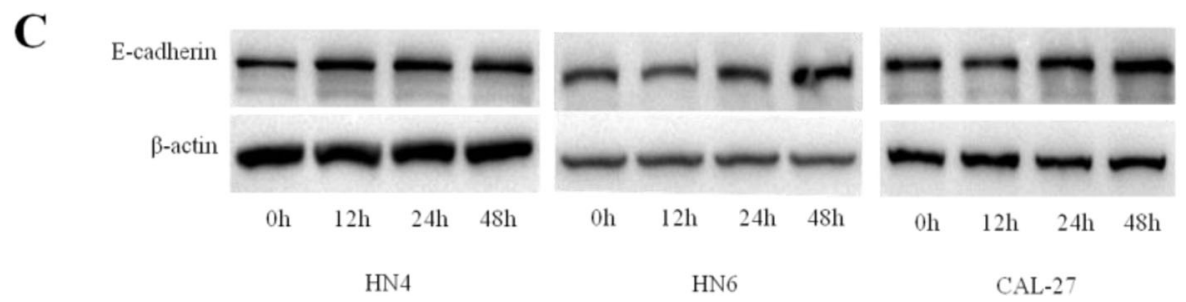

Fig. 3 Increased adhesion of C. albicans onto zymosan-treated OSCC cells 
including WSU-HN4, WSU-HN6 and CAL27 (Fig. 3b). It has been reported that E-cadherin plays an important role in the bacterial adhesion [19]. Thus, we determined the expression of E-cadherin by western blot, and the Ecadherin was more highly expressed in OSCC cells treated with ZYM for $48 \mathrm{~h}$ (Fig. 3c).

\section{Elevated IL-1 $\beta$ production in OSCC cells treated with zymosan is observed}

The pro-inflammatory cytokines including IL-6, IL-8, TNF- $\alpha$ and IL- $1 \beta$ in the culture supernatant from WSUHN4, WSU-HN6 and CAL27 cell lines treated with/ without zymosan were detected. By statistical analysis, there was a significant difference in the level of IL- $1 \beta$ produced by ZYM-treated WSU-HN4 $(p=0.0482)$ and ZYM-treated CAL27 cells $(p=0.0451)$ compared with controls (Fig. 4a). However, the concentration of IL- $1 \beta$ from WSU-HN6 cells treated with/without zymosan was below $5 \mathrm{pg} / \mathrm{ml}$. Then, we determined the dynamic level of IL-1 $\beta$ in WSU-HN4 and CAL27 cell lines, and the results showed an increased time-dependent tendency (Fig. 4b). Moreover, when treated with ZYM, OSCC cells secreted significantly more IL-1 $\beta$, which was indicative of an inflammatory response in the OSCC (Fig. 4b).

\section{NLRP3 inflammasome is activated in zymosan-treated OSCC cells}

Activation of the NLRP3 inflammasome is the main path to produce IL-1 $\beta$, and then we determined the expression of NLRP3, ASC and caspase-1 by RT-PCR. The expression of NLRP3, ASC and caspase-1 was enhanced in WSU-HN4 and CAL27 cells (Fig. 5a). The expression of IL-1 $\beta$ was highly enhanced in OSCC cells at both the mRNA and protein levels (Figs. 4b, 5b). These data suggested that zymosan could trigger the NLRP3 inflammasome and that NLRP3/IL-1 $\beta$ was also activated in OSCC cells when treated with the fungal cell wall component zymosan.

\section{Discussion}

In the present study, we found that zymosan from the fungal cell wall promotes the proliferation of OSCC cells via the TLR2/MyD88/NF- $\mathrm{kB}$ signaling pathway. In addition, zymosan could promote the expression of E-

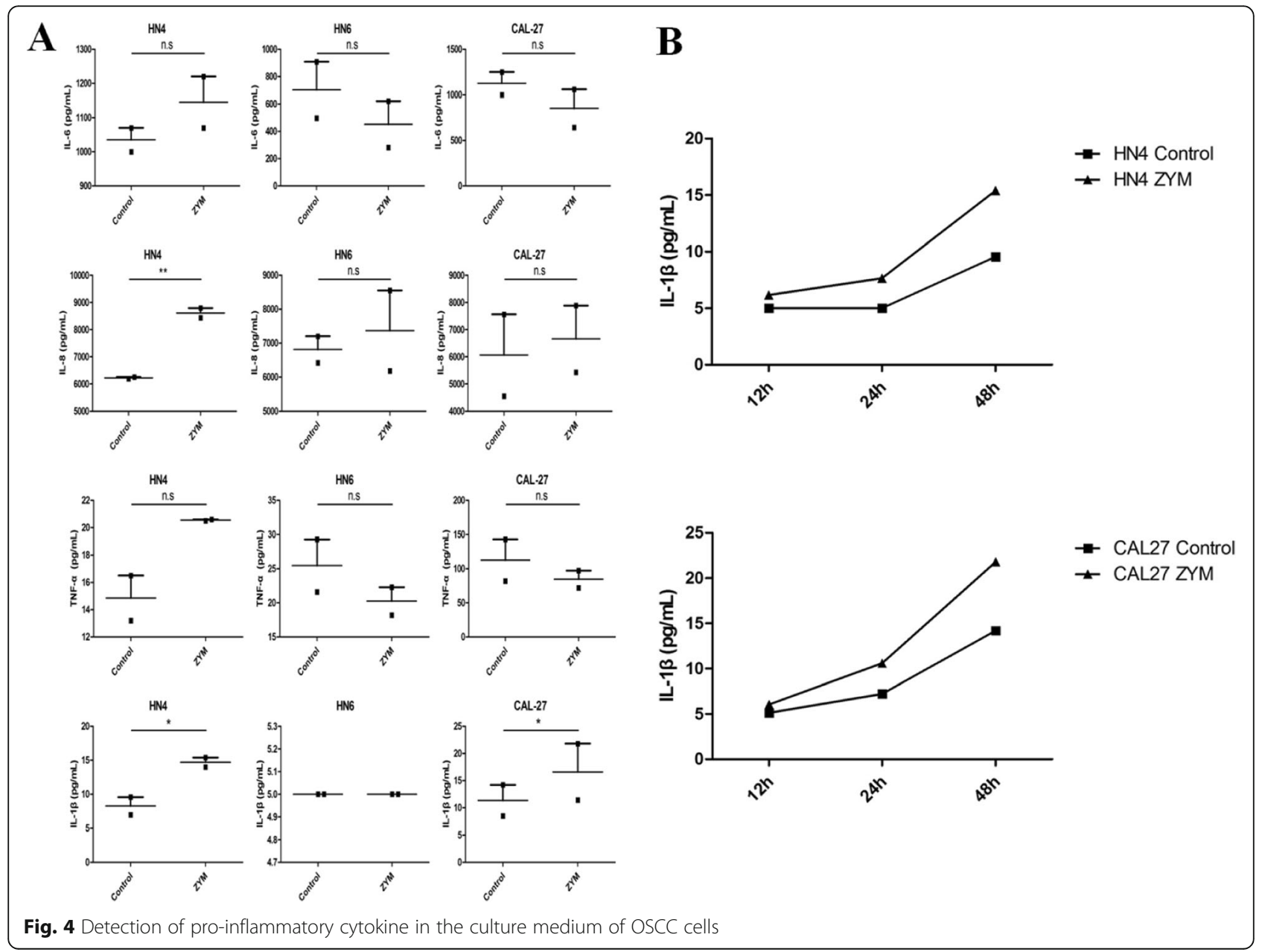




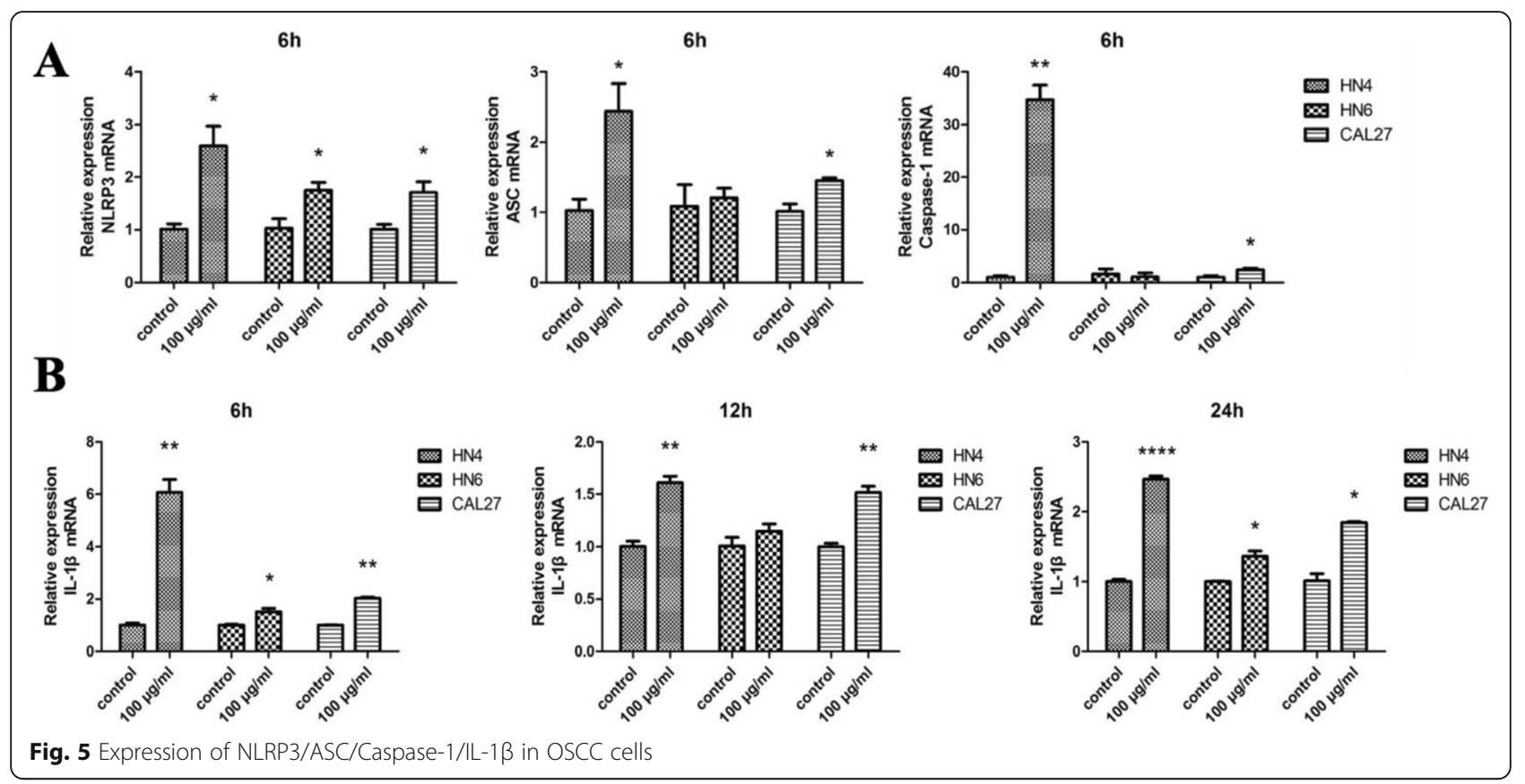

cadherin to enhance the adhesion of $C$. albicans onto OSCC cells and could further increase IL- $1 \beta$ production by OSCC cells. These results can provide information to better understand the interaction between $C$. albicans and oral cancer (Fig. 6).

As the main type of head and neck squamous cell carcinoma (HNSCC), oral cancer has been a significant clinical problem worldwide. There is a geographic variation in the incidence of oral cancer, and the countries in South Asia are traditionally considered high-occurrence places [20]. High risk factors for oral cancer include heavy smoking, excessive alcohol usage and betel chewing. Furthermore, microbiological infections, such as HPV infection and subsequent inflammation, may also increase the risk of oral cancer, while other microorganisms such as $P$. gingivalis, $F$. nucleatum and $C$. albicans, play a significant role in the process of oral cancer [21-24]. However, the detailed mechanism linking these microbes and oral cancer remains unknown. Here, we found that zymosan could promote the proliferation of OSCC in vitro via the traditional receptor TLR2. It has been reported that the TLR2-regulated gene signature is associated with tumour growth and that TLR2-dependent inflammation mediates tumour metastasis $[25,26]$. Moreover, other TLRs, such as TLR3 and TLR4, are also expressed on OSCC $[17,27]$. These results suggested that PMAPs play a pivotal role in the interaction of oral cancer and microbiota and that targeting TLRs in OSCC is a promising therapeutic method. Moreover, an elevated number of $C$. albicans was observed in OSCC cells when treated with zymosan, which implied increased adhesion/interaction between C. albicans and OSCC. This experiment could explain the phenomenon that C. albicans is higher in patients with OSCC or leukoplakia than in those without oral pathology. E-cadherin was reported to play a significant role in the adhesion of bacteria onto host cells [19], and here, we also detected higher levels of E-cadherin in OSCC cells after ZYM treatment for $48 \mathrm{~h}$, indicative of E-cadherin in the adhesion of $C$. albicans onto

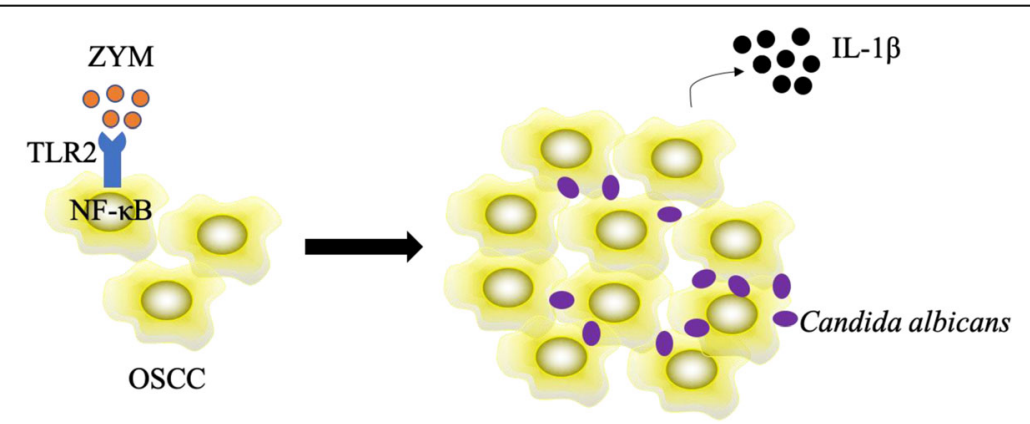

Fig. 6 Schematic diagram of this study 
OSCC. However, the detailed role of E-cadherin needs to be confirmed in animal models or clinical samples.

Recently, it was reported that $P$. gingivalis promoted oral carcinogenesis and aggravated the disturption of fatty acid metabolism, indicating a close association of $P$. gingivalis, lipid metabolism and oral carcinogenesis [21]. With the increased attention on microbiology, increasing research has shed light on the interaction between microbiota and cancers. Dejea et al demonstrated a synergistic interaction between two carcinogenic bacteria with different toxins and established the concept of microbial networks in carcinogenesis [28, 29]. As a key element in oral cancers, inflammation plays a significant role in the crosstalk between tumours, immune cells and microorganisms [30], and infections usually triggers inflammatory processes. Here, we found that the fungal cell wall component zymosan was involved in OSCC cells secreting significantly more pro-inflammatory cytokine IL-1 $\beta$ through the NLRP3/IL-1 $\beta$ pathway, indicating an inflammatory response in the OSCC. It is interesting to find that OSCC cells could secrete proinflammatory cytokines (such as IL-1 3 ) and be influenced by microbiota or their cell components, which indicates a more complex interaction between cancer cells, immune cells and microbiota in tumour microenvironment. Another report from our lab revealed that NLRP3 inflammasome-activated IL-1 $\beta$ promoted 5-FU resistance in OSCC both in vitro and in vivo [31], and combining these data, it can be inferred that the presence of $C$. albicans in oral cancer may influence the effect of chemotherapy by inducing IL- $1 \beta$ production, which was also a potential target for treating oral cancer.

Despite some interesting findings in the current study, there are still some limitations: 1) all the results were based on in-vitro experiments; 2) the mechanism explored in the current study needs further confirmation by more experiments, such as siRNA transfection; and 3) the mechanism should be verified by animal experiments and clinical human samples.

\section{Conclusion}

In summary, the fungal cell wall component zymosan promoted OSCC proliferation, IL- $1 \beta$ production and C. albicans adhesion to OSCC in this study, providing information to better understand the interaction between C. albicans and oral cancer.

\footnotetext{
Abbreviations

OSCC: Oral squamous cell carcinoma; HNSCC: Head and neck squamous cell carcinoma; CCK-8: Cell counting kit-8; ZYM: Zymosan; NBMA: Nnitrosobenzylmethylamine; TLR: Toll-like receptor; PRR: Pattern recognition receptor; DMEM: Dulbecco's modified Eagle's medium; SDA: Sabouraud dextrose agar; PMSF: Phenylmethanesulfonylfluoride; SDS-PAGE: Sodium dodecyl sulfate-polyacrylamide gel electrophoresis; PVDF: Polyvinylidene difluoride; TBST: Tris-buffered saline/Tween 20; MyD88: Myeloid differentiation primary response protein 88; NLRP3: NACHT, LRR and PYD
}

domains-containing protein 3; IL: Interleukin; 5-FU: 5-Fluorouracil; PCR: Polymerase chain reaction

\section{Acknowledgments}

We appreciated the help from Dr. Yantao Duan, Dr. Wei Wei and Qu Xu in the experiments.

\section{Authors' contributions}

Conceived and designed the experiments: XC, QL, FC. Performed the experiments: XC, JD, MY, RZ. Analysed the data: XC, QL. Contributed reagents/materials/analysis tools: XC, FC. Wrote the manuscript: X.C, QL, FC. The author(s) read and approved the final manuscript.

\section{Funding}

This work was supported by National Natural Science Foundation of China (81870762, 81702674), China Scholarship Council (CSC No. 201806230234), Shanghai Sailing Program (19YF1427500), Youth program from Shanghai Municipal Commission of Health and Family Planning (No. 20184Y0025) and fundamental research program funding of Ninth People's Hospital affiliated to Shanghai Jiao Tong University School of Medicine (No. JYZZ013, JYZZ043).

\section{Availability of data and materials}

All data generated or analyzed during this study are included in this article, and the data is also available from the corresponding author on reasonable request.

\section{Ethics approval and consent to participate}

This study was approved by the Ethics Committee of Shanghai Ninth People's Hospital.

\section{Consent for publication}

Not applicable.

Competing interests

The authors have declared that no competing interest exists.

Received: 27 April 2020 Accepted: 21 July 2020

Published online: 31 July 2020

\section{References}

1. Chi AC, Day TA, Neville BW. Oral cavity and oropharyngeal squamous cell carcinoma--an update. CA Cancer J Clin. 2015;65:401-21.

2. Leemans $C R$, Braakhuis BJ, Brakenhoff RH. The molecular biology of head and neck cancer. Nat Rev Cancer. 2011;11:9-22.

3. Yu T, Guo F, Yu Y, Sun T, Ma D, Han J, et al. Fusobacterium nucleatum promotes chemoresistance to colorectal cancer by modulating autophagy. Cell. 2017;170:548-63.e516.

4. lida N, Dzutsev A, Stewart CA, Smith L, Bouladoux N, Weingarten RA, et al. Commensal bacteria control cancer response to therapy by modulating the tumor microenvironment. Science. 2013:342:967-70.

5. Jin C, Lagoudas GK, Zhao C, Bullman S, Bhutkar A, Hu B, et al. Commensal microbiota promote lung Cancer development via $\gamma \delta$ T cells. Cell. 2019;176: 998-1013.

6. La Rosa GRM, Gattuso G, Pedullà E, Rapisarda E, Nicolosi D, Salmeri M. Association of oral dysbiosis with oral cancer development. Oncol Lett. 2020;19(4):3045-58.

7. Wang F, Meng W, Wang B, Qiao L. Helicobacter pylori-induced gastric inflammation and gastric cancer. Cancer Lett. 2014;345:196-202.

8. Karpinski TM. Role of oral microbiota in cancer development. Microorganisms. 2019;7:E20.

9. Rubinstein MR, Wang X, Liu W, Hao Y, Cai G, Han YW. Fusobacterium nucleatum promotes colorectal carcinogenesis by modulating $\mathrm{E}$ cadherin/beta-catenin signaling via its FadA adhesin. Cell Host Microbe. 2013:14:195-206.

10. Zhang L, Liu Y, Zheng HJ, Zhang CP. The Oral microbiota may have influence on Oral Cancer. Front Cell Infect Microbiol. 2019:9:476.

11. McCullough M, Jaber M, Barrett AW, Bain L, Speight PM, Porter SR. Oral yeast carriage correlates with presence of oral epithelial dysplasia. Oral Oncol. 2002;38:391-3. 
12. Perera M, Al-Hebshi NN, Perera I, Ipe D, Ulett GC, Speicher DJ, et al. A dysbiotic mycobiome dominated by Candida albicans is identified within oral squamous-cell carcinomas. J Oral Microbiol. 2017;9:1385369.

13. Teles R, Teles F, Frias-Lopez J, Paster B, Haffajee A. Lessons learned and unlearned in periodontal microbiology. Periodontology. 2000;62:95-162.

14. Domingues-Ferreira M, Grumach AS, Duarte AJ, De Moraes-Vasconcelos D. Esophageal cancer associated with chronic mucocutaneous candidiasis. Could chronic candidiasis lead to esophageal cancer? Med Mycol. 2009;47: 201-5.

15. Mohd Bakri M, Mohd Hussaini H, Rachel Holmes A, David Cannon R, Mary RA. Revisiting the association between candidal infection and carcinoma, particularly oral squamous cell carcinoma. J Oral Microbiol. 2010;2:5780.

16. Mogensen TH. Pathogen recognition and inflammatory signaling in innate immune defenses. Clin Microbiol Rev. 2009;22(2):240-73.

17. Luo Q, Hu S, Yan M, Sun Z, Chen W, Chen F. Activation of toll-like receptor 3 induces apoptosis of oral squamous carcinoma cells in vitro and in vivo. Int J Biochem Cell Biol. 2012;44:1266-75.

18. Pikarsky E, Porat RM, Stein I, Abramovitch R, Amit S, Kasem S, et al. NFkappaB functions as a tumour promoter in inflammation-associated cancer. Nature. 2004;431 (7007):461-6.

19. Ma LL, Sun ZH, Xu YL, Wang SJ, Wang HN, Zhang H, et al. Screening host proteins required for bacterial adherence after H9N2 virus infection. Vet Microbiol. 2018;213:5-14.

20. Fu JY, Wu CX, Zhang CP, Gao J, Luo JF, Shen SK, et al. Oral cancer incidence in Shanghai - a temporal trend analysis from 2003 to 2012. BMC Cancer. 2018:18:686.

21. Wu JS, Zheng M, Zhang M, Pang X, Li L, Wang SS, et al. Porphyromonas gingivalis promotes 4-Nitroquinoline-1-oxide-induced Oral carcinogenesis with an alteration of fatty acid metabolism. Front Microbiol. 2018;9:2081.

22. Al-Hebshi NN, Nasher AT, Maryoud MY, Homeida HE, Chen T, Idris AM, et al. Inflammatory bacteriome featuring Fusobacterium nucleatum and Pseudomonas aeruginosa identified in association with oral squamous cel carcinoma. Sci Rep. 2017:7:1834.

23. Alnuaimi AD, Wiesenfeld D, O'Brien-Simpson NM, Reynolds EC, McCullough MJ. Oral Candida colonization in oral cancer patients and its relationship with traditional risk factors of oral cancer: a matched case-control study. Oral Oncol. 2015:51:139-45.

24. Zhao H, Chu M, Huang Z, Yang X, Ran S, Hu B, et al. Variations in oral microbiota associated with oral cancer. Sci Rep. 2017;7(1):11773.

25. West AC, Tang K, Tye H, Yu L, Deng N, Najdovska M, et al. Identification of a TLR2-regulated gene signature associated with tumor cell growth in gastric cancer. Oncogene. 2017;36(36):5134-44.

26. Kim S, Karin M. Role of TLR2-dependent inflammation in metastatic progression. Ann N Y Acad Sci. 2011:1217:191-206.

27. Sun Z, Luo Q, Ye D, Chen W, Chen F. Role of toll-like receptor 4 on the immune escape of human oral squamous cell carcinoma and resistance of cisplatin-induced apoptosis. Mol Cancer. 2012;11:33.

28. Dejea CM, Fathi P, Craig JM, Boleij A, Taddese R, Geis AL, et al. Patients with familial adenomatous polyposis harbor colonic biofilms containing tumorigenic bacteria. Science. 2018:359:592-7.

29. Tomkovich S, Jobin C. Microbial networking in cancer: when two toxins collide. Br J Cancer. 2018;118:1407-9.

30. Elinav E, Nowarski R, Thaiss CA, Hu B, Jin C, Flavell RA. Inflammation-induced cancer: crosstalk between tumours, immune cells and microorganisms. Nat Rev Cancer. 2013:13:759-71.

31. Feng $X$, Luo $Q$, Zhang $H$, Wang $H$, Chen W, Meng G, et al. The role of NLRP3 inflammasome in 5-fluorouracil resistance of oral squamous cell carcinoma. J Exp Clin Cancer Res. 2017;36:81

\section{Publisher's Note}

Springer Nature remains neutral with regard to jurisdictional claims in published maps and institutional affiliations.

Ready to submit your research? Choose BMC and benefit from:

- fast, convenient online submission

- thorough peer review by experienced researchers in your field

- rapid publication on acceptance

- support for research data, including large and complex data types

- gold Open Access which fosters wider collaboration and increased citations

- maximum visibility for your research: over $100 \mathrm{M}$ website views per year

At $\mathrm{BMC}$, research is always in progress.

Learn more biomedcentral.com/submissions 